\title{
UPAYA GURU DALAM MEMBIASAKAN KARAKTER MELALUI PEMBELAJARAN AQIDAH AKHLAK DI MI MA'ARIF
}

\author{
Seka Andrean ${ }^{1}$ dan Muqowim ${ }^{2}$ \\ ${ }^{1,2}$ Pascasarjana Universitas Islam Negeri Sunan Kalijaga Yogyakarta \\ Email: sekaandrean28@gmail.com ${ }^{1}$ \\ Website: \\ https://jurnal.uinantasari.ac.id/index.php/adzka \\ Received: 19 Mei 2020; Accepted: 16 Juni 2020; Published: 16 Juni 2020
}

\begin{abstract}
The learning process carried out by the teacher should be able to create a pleasant and efficient learning atmosphere. Teaching and learning activities should also be aimed at habituating character values to develop a student's personality. This study aims to find out about the efforts of teachers to familiarize the character of students through learning Aqeedah Morals. This study uses a qualitative method. Data collection techniques used were interviews, observation and documentation with the subject being educators and students. Data analysis was performed by data reduction, data display and conclusion drawing. The results of the study are the efforts of teachers to provide character habituation to students through learning aqidah morals, can be applied with techniques namely: provide an explanation of the character, provide habituation to children so that they are accustomed to behave in character behavior, the learning process is carried out interactively, choose and develop teaching and learning techniques that have the greatest opportunity so that goals in the teaching and learning process can be achieved, and increase activities by applying behavior and character traits.
\end{abstract}

Key Words: aqidah akhlak; character; habituation; learning.

\begin{abstract}
ABSTRAK
Proses pembelajaran yang dilaksanakan oleh guru seharusnya bisa menciptakan suasana belajar yang menyenangkan dan efesien. Kegiatan belajar mengajar juga sebaiknya ditujukan kepada pembiasaan nilai-nilai karakter untuk berkembangnya kepribadian seorang murid. Penelitian ini bertujuan mengetahui tentang upaya guru dalam membiasakan karakter peserta didik melalui pembelajaran Aqidah Akhlak. Penelitian ini menggunakan metode kualitatif. Teknik pengumpulan data yang digunakan yaitu wawancara, observasi dan dokumentasi yang subjeknya berupa pendidik dan peserta didik. Analisis data dilakukan dengan reduksi data, display data dan penarikan kesimpulan. Hasil dari penelitian yaitu upaya guru dalam memberikan pembiasaan karakter pada peserta didik melalui pembelajaran aqidah akhlak, dapat diterapkan dengan teknik yaitu: memberikan penjelasan mengenai karakter, memberikan pembiasaan terhadap anak agar terbiasa melakukan tingkah laku yang berkarakter, proses pembelajaran yang dilakukan berlangsung secara interaktif, memilih dan mengembang tehnik belajar mengajar yang mempunyai kesempatan paling besar agar tujuan dalam proses belajar mengajar dapat tercapai, dan menambah kegiatan dengan mengaplikasikan tingkah laku dan sikap yang berkarakter.
\end{abstract}

Kata Kunci: aqidah akhlak; karakter; pembelajaran; pembiasaan

\section{PENDAHULUAN}

Pendidikan merupakan usaha dalam membimbing dan mengembangkan kepribadian seseorang, baik itu berkaitan dengan prinsip ruhaniyyah ataupun berkaitan dengan prinsip jasmaniyyah (Ilahi \& Ratri, 2012, hlm. 25). Berkaitan dengan pembangunan bangsa, 
pendidikan ialah bagian yang utama dalam menunjang sebuah keberhasilan bangsa. Dengan adanya pendidikan yang berkualitas, maka suatu bangsa akan menatap sebuah masa depan yang cerah. Pendidikan bisa dilaksanakan dengan upaya yang baik dan terstruktur agar membuat suasana belajar yang nyaman serta prosedur pembelajarannya bisa dilakukan dengan baik, agar anak didik bisa lebih aktif dalam mengembangkan kemampuannya untuk mempunyai energi spiritual kereligiusan, penanganan diri, jati diri, pandai dalam budi pekerti, serta keterampilan yang dibutuhkan oleh masyarakat, bangsa, dan negara. (Munandar, 2012, hlm. 6).

Pendidikan juga berperan sebagai kegiatan humanisasi dalam memberikan arahan kepada manusia untuk bisa menjalani kehidupan sesuai dengan kaidah bermoral, sebab pada hakikatnya manusia diciptakan untuk bermoral. Manusia diarahkan harus dalam menerapkan nilai-nilai sesuai dengan kodratnya dengan adanya pendidikan. Selain dengan sang maha pecipta, moral juga berhungan erat dengan antar manusia serta lingkungannya. Pendidikan dalam hal ini seharusnya tidak mengurangi kegiatan belajar mengajar, namun juga sanggup mensinkronkan antara intelektual dengan keperluan moral.

Terjadinya demoralisasi di sebuah pendidikan disebabkan karena kegiatan pembelajaran adab dan akhlak cenderung hanya sekedar teks dan tidak adanya persiapan anak untuk menjalani hidup yang sifatnya kontradiktif. Disamping itu pendidikan agama juga merupakan sebuah alat yang ampuh untuk penginternalisasian karakter luhur kepada peserta didik. (Agus Wibowo, 2012: 55). Padahal faktanya pendidikan agama hanya sekedar mengajarkan dasardasar agama. Oleh sebab itu, pendidikan agama semakin kesini semakin kehilangan perannya sebagai media yang mengarahkan anak didiknya agar dapat memahami serta mengamalkan ajaran agamanya.

Pendidikan saat ini dihadapkan pada berbagai masalah. Salah satu yang menjadi permasalahan yaitu menurunnya norma suatu kehidupan, baik itu sosial ataupun etika moral dalam praktik kehidupan sekolah yang dapat mengakibatkan terjadinya sejumlah perilaku negatif yang sangat merisaukan masyarakat. Hal tersebut antara lain makin banyaknya penyimpangan berbagai norma kehidupan agama dan sosial kemasyarakatan. (Nurdyansyah, 2016). Oleh karena itu diperlukan adanya pendidikan karakter.

Karakter berasal dari bahasa Yunani yaitu "to mark" ialah menekankan kebiasaan dalam menerapkan nilai-nilai kebajikan dalam wujud tingkah laku.(Hamdani Hamid, 2013: 31). Secara etimologi kata karakter dapat berupa karakter, kepribadian, budi pekerti, atau sifat kejiwaan. Karakter ialah watak atau kepribadian yang dimiliki oleh seseorang dengan karakter maka seseorang akan dapat membedakan antara seseorang dengan orang lain. Pengertian karakter biasanya lebih indentik dengan sebutan akhlak ataupun kepribadian. Kepribadian merupakan sebuah karakteristik pada diri seseorang yang memiliki sifat khas hal yang demikian biasanya berasal dari pengaruh lingkungan yang diterimanya, contohnya seperti dari keluarga dari kecil atau bawaan sejak lahir. (Zainal Aqib, 2012: 118).

Karakter secara khusus dapat diartikan sebagai sebuah nilai khas dari segi kebaikan, perbuatan baik, menerapkan kehidupan dalam kebaikan, dan membuat efek yan baik kepada dirinya sendiri beserta lingkunganya yang tertanam dalam diri sendiri dan dimanifestasikan melalui tingkah laku. Karakter ialah bagian dari ciri khas orang yang di dalamnya terkandung nilai, kompetensi, kedudukan moral, ketabahan jika berhadapan dengan berbagai tantangan dan kesulitan. (Anas Salahudin and Irwanto Alkrienciehie, 2013: 42). Sederhananya, karakter ditafsirkan sebagai pola pemikiran dan bersikap unik bagi semua orang untuk bertahan hidup dan bekerja bersama dengan lingkungan keluarganya, komunitas, bangsa dan negara. Dalam konteks moral, perilaku moral, dan sikap moral, sangatlah berhubungan erat dengan karakter (Muchlas Samani dan Hariyanto, 2011: 43). Kehilangan karakter pada diri sendiri akan menyebabkan hilangkan identitas generasi selanjutnya, sejalan dengan tulisan William 
Franklin Graham Jr. Yang berbunyi: "When wealth is lost, nothing is lost; when health is lost, something is lost; when character is lost, everything is lost"(Muchlas Samani dan Hariyanto, 2013: 2). Dengan demikian, karakter ialah dasar-dasar nilai dalam berperilaku yang dijadikan sebagai pedoman dalam hubungan timbal balik antar sesama manusia (Bariah dan Assya'bani, 2019: 141)

Dari beberapa pengertian di atas bahwasanya pendidikan karakter memiliki beberapa komponen yaitu berkembangnya nilai-nilai berkarakter dari hasil pendidikan, adanya kerja sama antar pihak guru dengan kepala sekolah, adanya prosedur internalisasi dan penjiwaan mengenai nilai karakter yang tertanam pada jati diri seorang siswa. Oleh diperlukan kerjasama antara semua pihak agar terbentuknya karakter yang diharapkan. Di sekolah, pendidikan karakter merupakan sebuah pembelajaran yang diarahkan pengembangan tingkah laku siswa berdasarkan atas nilai-nilai tertentu yang telah ditetapkan dari sekolahannya. Adapun pendidikan karakter di sekolah mengandung makna sebagai berikut: (Purniadi Putra, 2018: 149)

a. Sebagai pendidikan yang tergabung kedalam bagian belajar mengajar yang terdapat di seluruh mata pelajaran.

b. Ditujukan kepada perkembangan tingkah laku siswa secara menyeluruh dengan beranggapan bahwa siswa merupakan kedalam organisme manusia yang mempunyai kemampuan dan berhak untuk dikembangkan.

c. Perkembangan tingkah laku siswa didasari pada nilai-nilai yang telah dibuat oleh suatu lembaga.

Terdapat beberapa tujuan pendidikan karakter di sekolah yaitu sebagai berikut: (Kesuma And Dharma, Dkk, 2011: 5)

a. Mengembangkan dan memperkuat pentingnya sebuah nilai kehidupan yang baik agar menjadi ciri khas yang dimiliki oleh anak.

b. Memperbaiki tingkah laku anak yang kurang tepat dari perkembangan nilai-nilai di suatu lembaga.

c. Mendirikan hubungan yang rukun bersama keluarga beserta lingkunganya untuk memikul tanggungjawab bersama dalam pendidikan berkarakter.

Pendidikan karakter merupakan pendidikan yang lebih utama dari pada pendidikan moral biasa, sebab pendidikan karakter bukan saja berkaitan sama sesuatu yang dianggap tepat dan kurang tepat, melainkan bagaimana caranya dalam menumbuhkan pembiasaan diri tentang sesuatu yang baik-baik di dalam hidup. Diharapkan dengan ini siswa mempunyai kepekaan dan penafsiran yang tinggi serta mempunyai keteguhan hati agar dapat mengaplikasikannya dengan sikap-sikap terpuji dalam kehidupan sehari-hari. (Fidiyanti, Asfiyak, dan Ertanti, 2019: 141). Jadi dengan adanya pendidikan karakter diharapkan anak terbiasa melakukan sesuatu hal positif dalam hidup.

Penerapan pembiasaan karakter untuk anak diperlukan adanya bantuan guru. Guru mempunyai tugas dan tanggung jawab utama di dalam kelas yakni menentukan kesukseskan kegiatan pembelajaran. Hal ini berarti bahwa hubungan timbal balik serta interaksi antara pendidik dan peserta didik selama kegiatan belajar mengajar sedang berlangsung akan memberikan efek yang tinggi untuk kesuksesan siswa (Pamuji, 2017: 236). Guru merupakan salah satu hal yang penting di dalam dunia pendidikan yang memiliki peran aktif untuk memposisikan kedudukannya sebagai tenaga pendidik yang profesional, serta tidaklah semata-mata sebagai tenaga pendidik yang hanya memberikan ilmu pengetahuannya saja, namun juga harus dapat menjadi seorang pendidik dan pembimbing yang mampu dalam menyampaikan arahan serta menuntun peserta didik ketika sedang belajar (Hadari, 2015: 123). Oleh sebab itu, seorang pendidik dapat optimal dalam menjalankan tugas dan tanggungjawabnya dengan baik. Tanggung jawab seorang pendidik selain untuk menjalin 
interaksi yang baik terhadap peserta didiknya, hendaknya seorang pendidik juga harus bertanggungjawab untuk membiasakan peserta didik dalam berperilaku berkarakter.

Aqidah Akhlak termasuk dalam bagian mata pelajaran di sekolah yang memiliki andil cukup besar dalam membantu mendorong siswa supaya dipelajari kemudian dipraktikkan aqidahnya tersebut dalam wujud kehidupan sehari-hari agar supaya menjadi kebiasaan diri sendiri untuk berbuat perilaku terpuji dan menghindarkan dari perilaku yang tercela. Akhlakul karimah merupakan bagian penting yang harus diterapkan kepada siswa agar menjadi sebuah kebiasaan diri dalam kehidupan sehari-hari, masyarakat dan bangsa. Terutama dalam rangka mencegah efek buruk dari era disrupsi dan kritis multidimensi yang telah menerpa bangsa dan Negara Indonesia kita (Putra, 2018b, hlm. 151). Oleh karena itu Aqidah Akhlak menjadi fokus dalam penelitian ini.

Pembelajaran akidah akhlak memiliki tujuan menunjukan dan meningkatkan keimanan siswa, sehingga dapat dioutputkan ke dalam bentuk aplikasi kehidupan sosial. Adapun implikasinya terhadap perilaku individu sebagai manusia beragama yakni teraplikasikannya perilaku terpuji melalui pembelajaran dan pemahaman melalui pencarian pengetahuan, kemudian menghayatinya, sehingga memberikan pengalaman kepada peserta didik terkait akidah dan akhlak. Selain itu, visi dari mata pelajaran akidah akhlak ialah mebentuk muslim yang berkembang dan memiliki kualitas iman juga taqwa kepada Pencipta, sehingga berdampak dalam menjalankan kehidupan bermasyarakat, berbangsa dan bernegara sekaligus pandangan hidup panjang untuk masa panjang besok.

Pembahasan tentang Aqidah sudah pasti kurang lengkap jika tidak di barengi dengan akhlak. Wujud dari pencapaian dan indikasi diri dari aqidah sesorang disebut dengan Akhlak. Adapun Akhlak sendiri berasal dari lughotul ngarobiyyah yakni bentuk jamak dari "khulukun", berarti karakter, tabiat, kebiasaan, peradaban yang bagus, dan terakhir adalah agama. (Subahri, 2015, hlm. 169) Sedangkan akhlak secara bahasa artinya adalah penciptaan. Dalam pembahasan mengenai agama, akhlak berarti kepribadian, budi pekerti, bawaan, etika, atau sikap seseorang (Ahmad Bangun Nasution And Rohani Hanun Siregar, 2013: 30). Dengan demikian. Berdasarkan hakekatnya, akhlak ialah sebuah keadaan atau sifat yang sudah tertanam didalam diri kita yang kemudian menjadi sebuah kepribadian.

Dengan demikian siswa sekolah dasar harus memiliki nilai-nilai akhlak, seperti sebagai berikut: a) mempunyai al-akhlaq al-karimah yang didalamnya terdiri dari: kedisiplinan, hidup yang bersih, kemudian ramah tamah, lalu sopan dan santun, mensyukuri nikmat, hidup apa adanya, tetap tidak sombong, kejujuran, sikap rajiin, sikap percaya kepada diri sendiri, sikap menyayangi, patuh dan ta'at, damai, saling bantu membantu, hormat menghormati, selalu amanah dalam menjalankan kewajibannya dan sebagainya. b) menjauhkan akhlak yang tidak baik yang didalamnya terdiri atas: perkataan buruk, memiliki hidup yang tidak bersih, berbohong, memiliki sifat sombong dan pemalas, durhaka kepada orang tua, berkhianat, iri dang denki, dan sebaginya. c) etika Islamiah yang didalamnya terdiri atas: etika kepada dirinya sendirii (seperti: etika saat memakan dan meminum, saat mmebersihkan bada, saat memejamkan mata, saat di wc, saat berkomunikasi kepada orang lain dan sebagainya (Didik Efendi, 2019: 12).

Dengan demikian dapat diketahui bahwa aqidah akhlak adalah usaha yang nyata dan tersusun dalam mempersiapkan siswa atau siswa agar saling kenal, saling memahami, saling menghayati dan saling beriman kepada tuhan yang maha Esa dan mengaplikasikannya kedalam sikap akhlak yang terpuji didalam hidup sehari-hari dengan berlandaskan Al-Qur'an dan Hadits, dengan melewati proses pembimbingan, memberikan pelajaran dan ujian, serta menggunakan pengalamaan yang sudah-sudah. Dibersamai dengan tuntutan yang menekankan agar saling hormat-menghormati sesama pemeluk agama lain dan menjaga hubungan toleransi dengan rukun sesama kaum beragama didalam masyarakat sehingga dapat 
diwujudkan dalam sebuah kesatuan dan persatuan bangsa terutama bangsa indonesia. Pembelajaran aqidah akhlak diharapkan dapat membentuk nilai karakter anak.

Penelitian sebelumnya pada jurnal edutech oleh Tatan, Nurhayati dan Indra tentang Penerapan Teori Pembiasaan Dalam Pembentukan Karakter Religi Siswa Di Tingkat Sekolah mendapatkan hasil penelitian bahwa setelah dilakukan treatment metode pembiasaan, pelaksanaan shalat lima waktu dan pembacaan ayat-ayat al-qur'an mengalami peningkatan yang cukup signifikan; dari 36,82\% menjadi 57,13\%, walaupun pelaksanaan shalat lima waktu belum dapat dilaksanaan tepat waktu oleh para siswa. (Mutakin, 2014). Kesimpulannya bahwa metode pembiasaan pada penelitian sebelumnya ini meningkatkan karakter anak. Persamaan penelitian ini dengan penelitian yang peneliti lakukan yaitu sama-sama membahas tentang karakter. Perbedaannya metode yang digunakan penelitian ini adalah R\&D dan peneliti menggunakan metode kualitatif.

Berdasarkan uraian tersebut, peneliti tertarik membahas artikel ini dengan tema "Upaya Guru dalam Membiasakan Karakter Melalui Pembelajaran Aqidah Akhlak di MI Ma'arif Candran. Dengan fokus penelitian sebagai berikut yaitu tentang bagaimana upaya guru dalam membiasakan karakter melalui pembelajaran akidah akhlak di MI Ma'arif Candran.

\section{METODE PENELITIAN}

Metode penelitian ini menggunakan penelitian dalam pendekatan kualitatif. Dengan menggunakan metode deskriptif (Wina Sanjaya, 2013: 47). Penelitian ini mendeskripsikan tentang bagaimana upaya guru dalam membiasakan karakter melalui pembelajaran Akidah Akhlak pada MI Ma'arif Candran, Sidoarum, Sleman, D.I Yogyakarta. Subjek dalam penelitian ini ialah peserta didik dan guru yang ada MI Ma'arif Candran, Sidoarum, Sleman, D.I Yogyakarta.

Teknik pengumpulan data yang digunakan adalah wawancara, observasi dan dikumentasi. Teknik wawancara yang digunakan adalah teknik wawancara tak terstruktur. Teknik observasi ini dilakukan dengan cara mengobservasi aktifitas guru dalam membiasakan karakter pada peserta didik dalam kegiatan belajar mengajar baik di kelas ataupun di luar kelas. Sedangkan teknik dokumentasi dilaksanakan dengan mencari dan mengumpulkan dokumen-dokumen berkaitan dengan perencanaan belajar mengajar yang telah direncanakan dengan khusus untuk memperoleh data mengenai pembiasaan berkarakter tersebut. Tenkik analisis data menggunakan reduksi data, display data dan penarikan kesimpulan.

\section{HASIL PENELITIAN DAN PEMBAHASAN}

Berdasarkan hasil observasi, wawancara dan dokumentasi yang dilakukan dalam penelitian ini, bahwasanya upaya yang dilakukan guru dalam membiasakan karakter anak adalah :

1. Menyeleksi, menentukan, dan mengembangkan metode pembelajaran yang mempunyai kesempatan besar demi mencapai sebuah tujuan dalam proses kegiatan pembelajaran.

Dalam upaya pembiasaan karakter, seorang guru mengupayakannya dengan beberapa cara yang terungkap dari hasil wawancara yaitu dengan SK yang mengatakan bahwa "Membiasakan pendidikan karakter pada peserta didik dilakukan dengan cara merancang perencanaan pembelajaran berdasarkan kurikulum yaitu berpedoman pada silabus dan RPP serta pemilihan bentuk pembelajaran yang disesuaikan dengan kondisi, karakteristik dan kemampuan siswa, agar pembelajaran berlangsung sesuai dengan tujuan yang diharapkan. Selanjutnya dengan cara memberi arahan pada peserta didik untuk berperilaku sesuai dengan karakter yang islami dan cara lain yang tepat yaitu mempraktekkan langsung perilaku yang sesuai dengan karakter peserta didik. Praktek yang dimaksudkan adalah wujud perilaku kita tampilkan di depan anak-anak sehingga peserta didik dapat meniru perilaku kita yang benar. Guru dapat mempraktekkan karakter saat makan harus duduk tidak boleh 
berjalan, sikap disiplin dan lain sebagainya. Praktek-praktek semacam itu akan menjadikan anak pondasi agar karakter terbentuk pada diri mereka". (SK, 2020) Dari wawancara ini bahwasannya cara yang dilakukan untuk membiasakan karakter melalui pembelajaran akidah akhlak adalah dengan merancang perencanaan pembelajaran. Perencanaa pembelajaran tersebut sisesuaikan dengan kurikulum yang berpedoman pada silabus dan RPP mata pelajaran aqidah akhlak.

Tabel 1. Penanaman Karakter Melalui Pembelajaran Aqidah Akhlak di MI Ma'arif Candran

\begin{tabular}{|c|c|c|c|}
\hline No & Variabel & Aspek Pengamatan & Deskripsi \\
\hline 1 & $\begin{array}{l}\text { Pembelajaran Aqidah } \\
\text { Akhlak }\end{array}$ & $\begin{array}{l}\text { Perencanaan } \\
\text { Pembelajaran }\end{array}$ & $\begin{array}{l}\text { - Perencanaan pembelajaran yang } \\
\text { didasarkan pada kurikulum yakni } \\
\text { mengacu kepada silabus dan RPP } \\
\text { - Seorang guru hendaknya menggunakan } \\
\text { media pembelajaran dan strategi yang } \\
\text { menyenangkan saat kegiatan } \\
\text { pembelajaran sedang berlangsung. Hal } \\
\text { ini sudah mencapai tujuan yang } \\
\text { diinginkan yaitu peserta didik sanggup } \\
\text { menguasai materi yang disampaikan } \\
\text { oleh guru dan bisa menerapkannya } \\
\text { dalam kehidupan siswa sehari-hari } \\
\text { hingga terbentuknya jiwa-jiwa ya } \\
\text { berkarakter baik. }\end{array}$ \\
\hline 2 & Pembiasaan Karakter & $\begin{array}{l}\text { Aktivitas siswa dalam } \\
\text { kegiatan pembelajaran } \\
\text { Aqidah Akhlak }\end{array}$ & $\begin{array}{l}\text { - Saat kegiatan pembelajaran, peserta } \\
\text { didik mempraktekkan secara otomatis } \\
\text { dari pelajaran yang sudah disampaikan } \\
\text { oleh guru. } \\
\text { - Siswa dapat menunjukkan karakter sikap } \\
\text { disiplin, sikap ramah terhadap kawan } \\
\text { dan guru saat di sekolahan, sikap adab } \\
\text { saat makan dan minum, saling mengasihi } \\
\text { dan tolong menolong antar sesama, serta } \\
\text { memiliki prilaku bertanggungjawab atas } \\
\text { dirinya sendiri. }\end{array}$ \\
\hline
\end{tabular}

Dokumentasi: Penanaman Karakter Melalui Pembelajaran Aqidah Akhlak di MI Ma'arif Candran.

Dalam perencanaan belajar Aqidah Akhlak untuk mengupayakan pembiasaan karakter yang dibuat oleh guru adalah persiapan perencanaan strategi guru dalam menerapkan karakter pada peserta didik dan menggunakan alat dalam pembelajaran serta pola pembelajarnya didasarkan pada tujuan yang diharapkan. Dimana tujuan belajar adalah selain untuk meningkatkan ilmu peserta didik, melainkan juga bisa dirubah tingkah laku peserta didik supaya menjadi orang yang lebih bagus lagi. Hal ini sesuai dengan pernyataan Kimble dan Garmezi tentang pengertian belajar bahwasanya belajar ialah suatu perubahan perilaku yang bersifat tetap yang berlangsung dari hasil pengalaman. Oleh karena itu persiapan yang disusun oleh guru hendaknya di sesuaikan dengan keadaan dan situasi, karakteristik serta kompetensi peserta didik itu sendiri. Namun hal demikian tetap harus mengacu kepada kurikulum pembelajaran yang berlaku yakni yang didasakan atas RPP dan silabus.

Dengan dilaksanakannya perencanaan tersebut, maka kegiatan belajar mengajar dapat berlangsung berdasarkan tujuan yang diinginkan, yaitu murid sanggup memahami materi serta 
mengaplikasikannya didalam kehidupan siswa sehari-hari hingga jadilah mereka dengan kepribadian yang terpuji. Perencanaan tidaklah pernah terpisahkan dengan alat, prosedur dan keadaan kelas yang dilaksanakan pendidik ketika berlangsungnya kegiatan belajar mengajar. Karena tugas guru ialah sebagai motivator dan fasilitator peserta didik maka tugas guru disini sangat mempengaruhi dalam pembangunan karakter anak didik. Dengan demikian seorang pendidik dituntut sanggup menyusun rencana belajar yang berkualitas dan menarik, supaya siswa dapat lebih semangat dalam meningkatkan belajar mereka dengan lebih baik.

2. Memberikan pemahaman tentang pentingnya berkarakter

Implementasi pembelajaran Aqidah Akhlak mengacu pada peraturan dan ketentuan yang sudah ditentukan dalam tiap-tiap kegiatan pembelajaran di suatu lembaga pendidikan. Termasuk dalam kegiatan pembelajaran dari masing-masing meteri pelajaran tetap berpedoman atas kurikulum ataupun silabus yang sudah ditentukan dari pemerintahan. Sehingga pihak sekolah hanya perlu melakukan pengelolaan dan penyusunan programprogram pembelajaran Akidah Ahlak yang berdasarkan atas kurikulum maupun silabus.

Demikian pula pada proses kegiatan pengaplikasian Aqidah Akhlak yang difokuskan dalam membentuk karakter siswa. Disini bukan saja mendalami aspek intelektual saja, namun juga harus mendalami karakter ataupun kepribadian siswa itu sendiri. Oleh sebab itu dalam mengupayakan pengaplikasiannya seorang pendidik harus sanggup memberikan pelajaran yang berkesan ketika kegiatan belajar mengajar sedang berlangsung dengan memanfaatkan berbagai referensi pembelajaran dan menghubungkannya bersama materi yang mau dipelajari. Dalam memberikan pembelajaran pendidik memberikan pemahaman juga tentang pentingnya karakter.

3. Membiasakan peserta didik untuk melaksanakan sikap berkarakter

Secara umum guru Aqidah Akhlak MI Ma'arif Candran memahami dan menyatakan sudah berupaya membina dan membiasakan karakter pada peserta didik. Dari wawancara yang telah dilakukan, usaha yang dilakukan guru dilaksanakan sesuai dengan visi dan misi MI Ma'arif Candran. Hal ini dikutip dari pernyataan SK menjelaskan bahwa "pemberian pemahaman kepada anak berkaitan dengan perbuatan baik dan buruk memang harus diupayakan di MI Ma'arif Candran. Dengan pemberian pemahaman tentang perilaku yang baik dan perilaku yang tidak baik, akan membentuk karakter atau kepribadian anak dengan baik pula dan juga anak harus mengetahui apa yang boleh dan apa yang tidak boleh dilakukan. Kita harus membiasakan diri anak pada perilaku yang baik, terutama melalui tauladan dari kita sebagai gurunya. Kita sebagai guru harus lebih banyak memberi contoh seperti kasih sayang, jujur, saling berbagi, dan saling menghargai. Anak juga harus diarahkan sikap dan perilakunya dalam pergaulan atau dalam kegiatan bermainnya yang terkadang juga diluar nilai-nilai yang baik dan benar. Dalam bermain saling memukul, menendang dan bahkan ada juga saling memaki, disini kita sebagai guru dituntut untuk mengarahkan dan mengingatkan mereka dengan kasih sayang dan kelembutan supaya mereka menjiwai hal baik dan benar". (SK, 2020)

Berdasarkan pernyataan tersebut bahwasannya dalam membiasakan karakter pada anak guru di MI Ma'arif Candran juga menjadi teladan yang baik untuk anak sehingga pembelajaran yang disampaikan bisa dibiasakan anak. Pembiasaan karakter pada peserta didik misalnya seperti membaca doa sebelum belajar, saling berbagi dan tolong menolong kepada teman, dan selalu menerapkan disiplin untuk masuk kelas.

4. Proses pembelajaran yang dilakukan berlangsung secara interaktif

Proses pembelajaran dilakukan secara interaktif agar terjadinya interaksi antara guru dan anak. Di MI Candran setelah memberikan pembelajaran guru memberi kesempatan kepada anak anak untuk mengajukan pertanyaan dan melakukan diskusi terhadap apa yang menjadi pembahasan. pendidik harus memperhatikan keaktifan murid saat kegiatan belajar 
mengajar sedang berlangsung. Sebab, hal yang demikian bisa dijadikan tolak ukur seorang guru dalam menilai ukuran siswa yang sanggup menguasai pelajaran Aqidah Akhlak

5. Menambah kegiatan yang sifatnya mempraktekan langsung tingkah laku berkarakter

Dalam membiasakan karakter upaya yang dilakukan guru tidak hanya tentang pembahasan materi saja, namun juga langsung mempraktekan langsung tentang tingkah laku berkarakter. Jadi dalam menyampaikan mata pembelajaran akidah akhlak misalnya tetang tolong menolong anak-anak diharapkan dan dicoba untuk mempraktekan langsung tentang apa yang telah dipelajari tersebut. Misalnya ketika ada anak sakit maka anak-anak akan menjenguk dan menolong temannya tersebut.

Dengan demikian beberapa nilai-nilai yang terkandung di dalam pendidikan karakter tersebut harus sungguh-sungguh ditanamkan pada seluruh diri peserta didik yang ada disekolah. Hal ini menunjukkan bahwa pembiasaan karakter melalui pembelajaran Aqidah Akhlak yang dilakukan oleh guru di tempat penelitian tersebut dapat memberikan hasil. Dengan demikian melalui pembelajaran Aqidah Akhlak dapat membiasakan karakter kepada peserta didik yang telah direncanakan secara efektif dan efisien.

\section{PENUTUP}

Berdasarkan uraian tersebut, dapat diambil kesimpulan bahwa upaya guru dalam membiasakan karakter pada peserta didik melalui proses pembelajaran aqidah akhlak di MI Ma'arif Candran sudah dilakukan dengan baik yaitu dengan cara: (1) menyeleksi, menentukan, dan mengembangkan metode pembelajaran yang mempunyai kesempatan besar demi mencapai sebuah tujuan dalam proses kegiatan pembelajaran, (2) memberikan pemahaman tentang pentingnya berkarakter, (3) membiasakan peserta didik untuk melaksanakan sikap berkarakter, (4) proses pembelajaran yang dilakukan berlangsung secara interaktif, (5) menambah kegiatan yang sifatnya mempraktekan langsung tingkah laku berkarakter. Dengan beberapa karakter yang diusahakan guru terhadap peserta didiknya diantaranya ialah: anak dapat menunjukkan karakter sikap disiplin, sikap ramah antar sesama kawan dan guru di sekolah, sikap adab saat makan dan minum, saling berbagi, menolong kepada sesama, ketaatan terhadap aturan serta memiliki sikap bertanggung jawab terhadap dirinya sendiri.

\section{DAFTAR PUSTAKA}

Agus Wibowo. (2012). Pendidikan Karakter: Strategi Membangun Karakter Bangsa Berperadaban. Yogyakarta:Pustaka Belajar.

Anas Salahudin, \& Irwanto Alkrienciehie. (2013). Pendidikan Karakter Pendidikan Berbasis Agama \& Budaya. Bandung:CV Pustaka Setia.

Bariah, K., \& Assya'bani, R. (2019). Integrasi Nilai Karakter dalam Pembelajaran Akidah Akhlak: Studi Pembelajaran Akidah Akhlak di MI Integral Al-Ukhuwwah Banjang. Al Qalam: Jurnal Ilmiah Keagamaan dan Kemasyarakatan, 3(2), 139-162.

Efendi, D. (2019). Proses pembentukan aqidah dan akhlak pada siswa sekolah dasar di kota Jayapura. Al-Adzka: Jurnal Ilmiah Pendidikan Guru Madrasah Ibtidaiyah, 9(1), 9-20.

Fidiyanti, N., Asfiyak, K., \& Ertanti, D. W. (2019). Upaya guru akidah akhlak dalam membentuk karakter peserta didik di mi ma'arif penanggungan. Jpmi: Jurnal Pendidikan Madrasah Ibtidaiyah, 1(3), 141-144.

Hadari, N. (2015). Organisasi Sekolah dan Pengelolaan Kelas Sebagai Lembagas Pendidikan. CV. Haji Masagung.

Hamdani Hamid. (2013). Pendidikan Karater Perspektif Islam. Bandung:Pustaka Setia.

Ilahi, M. T., \& Ratri, R. K. (2012). Revitalisasi Pendidikan Berbasis Moral. Ar-Ruzz Media. 
Kesuma, \& Dharma, dkk. (2011). Pendidikan Karakter Kajian Teori dan Praktek di Sekolah. Bandung:PT Remaja Rosdakarya.

Marzuki. (2015). Pengintegrasian Pendidikan Karakter dalam Pembelajaran di Sekolah. FIS Yogyakarta:Universitas Negeri Yogyakarta.

Muchlas Samani dan Hariyanto. (2013). Konsep dan Model Pendidikan Karakter, cet. 3. Bandung:PT Remaja Rosdakarya.

Muchlas Samani, \& Hariyanto, M.S. (2011). Konsep Dan Model Pendidikan Karakter. Bandung:PT Remaja Rosdakarya.

Munandar, U. (2012). Pengembangan kreativitas anak berbakat. Departemen Pendidikan \& Kebudayaan : Reneka Cipta.

Mutakin, T. Z. (2014). Penerapan teori pembiasaan dalam pembentukan karakter religi siswa di tingkat sekolah dasar. Jurnal Edutech, 13(3), 361-373.

Nurdyansyah, N. (2016). Developing ict-based learning model to improve learning outcomes ipa of sd fish market in sidoarjo. Jurnal Tekpen, 1(2), Article 2.

Pamuji, Z. (2017). Implementasi manajemen pembelajaran ramah anak dalam menanamkan karakter disiplin (studi pada upaya guru kelas 1a di ma muhammadiyah beji). Jurnal Studi Islam Gender Dan Anak, 12(2), 235-255.

Putra, P. (2018). Implementasi pendidikan karakter dalam pembelajaran aqidah akhlak (studi multi kasus di min sekuduk dan min pemangkat kabupaten sambas. Al-Bidayah: Jurnal Pendidikan Dasar Islam, 9(2), 147-156.

Putra, P. (2018b). Implementasi pendidikan karakter dalam pembelajaran aqidah akhlak (studi multi kasus di MIN Sekuduk dan MIN Pemangkat Kabupaten Sambas). Al-Bidayah: Jurnal Pendidikan Dasar Islam, 9(2), 147-156.

Subahri. (t.t.). Aktualisasi akhlak dalam pendidikan islamuna. Jurnal Studi Islam. Vol. 2. No. 2. (5 Desember 2015).

Subahri, S. (2015). Aktualisasi akhlak dalam pendidikan. Islamuna: Jurnal Studi Islam, 2(2), $167-182$.

Wina Sanjaya. (2013). Penelitian Pendidikan: Jenis, Metode, dan Prosedur. Jakarta:Kencana.

Zainal Aqib. (2012). Pendididkan Karakter di Sekolah Membangun Karakter dan Kepribadian Anak. Bandung:CV Yrama Media. 